\title{
Review: Kandungan Serat dan Protein Pakan Ternak Jangkrik (Gryllus sp) yang Bersumber dari Beberapa Jenis Sayuran dan Hijauan
}

\author{
Maria Aditia Wahyuningrum \\ Program Studi Agroteknologi Fakultas Pertanian Universitas Respati Indonesia \\ Email: tia@urindo.ac.id
}

\begin{abstract}
Abstrak
Jangkrik merupakan salah satu ternak satwa alternatif yang saat ini mulai digemari masyarakat. Jangkrik termasuk pemakan segala atau omnivore yaitu mampu memanfaatkan sayuran, buah-buahan, hasil samping produk. Jangkrik menyukai makanan berupa sayuran dan buah-buahan yang mengandung air seperti sayuran sawi, kol, gambas, jagung muda, wortel, kangkung, buah pepaya dan lain-lain. Kecepatan pertumbuhan jangkrik ditentukan oleh pakan yang berkualitas dan mengandung semua nutrien yang seimbang, untuk mempercepat pertumbuhan jangkrik dapat diberikan pakan ayam broiler seperti BR-I atau BR-II ditambah sayuran. Pakan jangkrik merupakan salah satu faktor yang sangat berpengaruh terhadap tinggi rendahnya produktivitas. Salah satu upaya meningkatkan produktivitas pakan dengan mencari alternative sumber pakan yang mudah didapat dan dengan harga terjangkau. Studi literature ini ingin member gambaran beberapa jenis sayuran yang digunakan sebagai alternative pakan jangkrik. Sayuran yang digunakan dalam beberapa penelitian pakan jangkrik antara lain sawi hijau, batang singkong muda, daun eceng gondok, daun kangkung dan daun singkong. Kandungan nilai gizi sayuran dan hijauan ini juga menjadi perhatian peneliti untuk terus mendapatkan komposisi ransum yang sesuai juga dapat menjadi solusi sumber pakan alternatif yang ekonomis.
\end{abstract}

Kata Kunci: jangkrik, sayuran, alternatif pakan, kandungan serat, kandungan protein

\begin{abstract}
Crickets are one of the alternative livestock that are now starting to be popular with the public. Crickets include all-eaters or omnivores, which are able to utilize vegetables, fruits, byproducts. Crickets like food in the form of vegetables and fruits that contain water such as mustard greens, cabbage, gambas, young corn, carrots, kale, papaya and others. The growth speed of crickets is determined by quality feed and contains all balanced nutrients, to accelerate the growth of crickets, broiler chicken feed such as BR-I or BR-II plus vegetables can be given. Cricket feed is one of the most influential factors on the high and low productivity. One of the efforts to increase feed productivity is to find alternative sources of feed that are easily available and at affordable prices. This literature study wants to give an overview of several types of vegetables that are used as an alternative to cricket feed. Vegetables used in several studies of feeding crickets include mustard greens, young cassava stems, water hyacinth leaves, kale leaves and cassava leaves. The content of the nutritional value of vegetables and forage is also a concern for researchers to continue to obtain an appropriate ration composition which can also be an economical alternative feed source solution.
\end{abstract}

Keywords: crickets, vegetables, feed alternatives, fiber content, protein content

http://ejournal.urindo.ac.id/index.php/pertanian 


\section{PENDAHULUAN}

Jangkrik (Gryllus $s p$ ) sangat berpotensi untuk dibudidayakan sebagai sumber protein alternative bagi pakan untuk berbagai jenis ikan dan burung. Jangkrik yang hidup di alam Indonesia sangat didukung oleh iklim dan cuaca. Makanan utama jangkrik adalah dedaunan, umbi-umbian, dan sayur-sayuran yang tumbuh di sawah atau tegalan, di semak-semak atau di hutan-hutan yang merupakan habitatnya untuk berkembang biak [1]. Manfaat dari serangga ini cukup banyak, mulai pakan burung atau ikan, diolah, dan yang tengah banyak dibicarakan adalah sebagai bahan makanan karena kandungan protein yang tinggi [2].

Jangkrik memiliki siklus hidup yang pendek tetapi mudah dalam pemeliharaan, dan mudah beradaptasi dengan pakan yang diberikan, serta modal cukup murah. Pengembangan peternakan tidak hanya pada ternak konfensional tetapi juga ternak non konfensional (satwa harapan). Jangkrik sebagai ternak non konfesional berpotensi sebagai sumber protein bagi unggas tetapi juga sebagai bahan pangan manusia [3]. Pemanfaatan jangkrik telah mengalami kemajuan menyebabkan permintaan di pasar saat ini terus meningkat pula. Sebagian besar kebutuhan jangkrik selama ini dipenuhi dari hasil tangkapan di alam bebas. Upaya memenuhi permintaan konsumen perlu dilakukan budidaya jangkrik secara intensif. Budidaya jangkrik secara intensif ini diharapkan dapat mensuplai kebutuhan pasar secara kontinyu dalam jumlah yang cukup [4].

Hasil penelitian lain mengungkapkan bahwa tepung jangkrik memiliki kandungan nutrisi dan asam-asam amino cukup lengkap [5]. Tepung jangkrik memiliki kandungan energy sebesar 4,87 kalori/gram, jauh di atas bahan makanan yang lain seperti kandungan sumber energy dalam jagung 2,73 kal/g, gandum 4,05 $\mathrm{kal} / \mathrm{g}$, daging atau ikan 4,27 kal/g, dan telur 4,36 $\mathrm{kal} / \mathrm{g}[6]$.

Jangkrik membutuhkan pakan yang cukup untuk pertumbuhan dan perkembangannya. Pertumbuhan sering juga didefinisikan sebagai pertambahan ukuran, berat, dan bertambahnya jumlah sel [7]. Biaya pakan jangkrik akan mahal bila diberi $100 \%$ pakan komersil. Usaha untuk mengurangi biaya produksi pakan tersebut harus mencari alternatif lain yaitu melakukan penggunaan bahan pakan yang murah dan ekonomis [8]. Sesuai dengan kebutuhan pakan jangkrik yang baik untuk peliharaan ialah hijauan, kacang-kacangan, buah-buahan, dan umbi-umbian yang masih muda serta sayursayuran. Sayur-sayuran yang masih segar diberikan pada jangkrik disamping dapat memenuhi kebutuhan makanan [9].

Pada studi literasi ini memberikan informasi awal kandungan nutrisi khususnya protein dan serat kasar beberapa jenis sayuran dan buah alternative pakan jangkrik antara lain 
sawi, buah dan daun pepaya, wortel, daun eceng gondok, daun kangkung dan daun singkong. Umumnya jangkrik menyukai sayuran, dedaunan dan buah-buahan yang mengandung air untuk makananya. Karena satwa ini tidak minum air seperti hewan lain pada umumnya [10].

\section{KANDUNGAN NUTRISI PAKAN}

Pada umur 10 - 40 hari, jangkrik membutuhkan pakan dengan kandungan protein sekitar 20-21\%. Jangkrik umur 30-40 hari merupakan masa pertumbuhan yang membutuhkan protein tinggi. Jangkrik membutuhkan nutrisi yang lebih tinggi pada umur 50 hari terutama kandungan proteinnya karena untuk persiapan aktifitas reproduksi, seperti pembentukkan alat reproduksi, perkawinan dan produksi telur [11].

Tabel 1. Kandungan Nutrisi (PK dan SK) Sayuran dan Buah Pakan Jangkrik

\begin{tabular}{|c|c|c|}
\hline Sumber Pakan & PK (\%) & SK (\%) \\
\hline Sawi hijau $^{12}$ & 26,26 & 23,92 \\
\hline Batang & 15,57 & 35,82 \\
\hline \multicolumn{3}{|l|}{ Singkong } \\
\hline \multicolumn{3}{|l|}{ muda $^{12}$} \\
\hline Daun Eceng & 11,20 & 29,30 \\
\hline \multicolumn{3}{|l|}{ Gondok ${ }^{11}$} \\
\hline Daun & 23,99 & 16,17 \\
\hline \multicolumn{3}{|l|}{ Kangkung ${ }^{11}$} \\
\hline Daun & 24,2 & 22,1 \\
\hline
\end{tabular}

Singkong ${ }^{11}$

\section{KEBUTUHAN PAKAN JANGKRIK}

Jangkrik merupakan serangga pemakan daun yang biasa hidup di alam bebas, umumnya pakan hijauan yang digunakan adalah sayuran, 17 preferensi pakan bagi serangga selain dari kandungan nutrisi di dalamnya, didasari juga oleh morfologi pakan seperti tekstur, kandungan dan teksturnya yang lembut serta memiliki kandungan air yang tinggi. Pakan yang cukup dibutuhkan untuk pertumbuhan perkembangbiakan dalam budidaya jangkrik, pemberian pakan pada jangkrik dilakukan sebanyak dua kali sehari. Cara pemberian pakan yang teratur dapat mengurangi kanibalisme, pakan yang diberikan terdiri atas hijauan dan sayuran yang berfungsi untuk memenuhi kebutuhan makan dan minum secara langsung [13].

Kebutuhan air jangkrik diperoleh dari sayuran segar yang diberikan tergantung dari umur jangkrik [14]. Anak jangkrik yang baru menetasakan memakan sisa cairan telurnya dan mulai diberikan pakan sayuran pada umur dua hari pakan yang diberikan adalah kosentrat sampai pada umur satu minggu, seterusnya akan diberikan hijauan berupa sayuran sampai dewasa atau panen.

\section{KESIMPULAN}


Dalam pengamatan pustaka ini diketahui sayuran dan hijauan yang akan digunakan harus diketahui kadar nutrisi khususnya protein dan serat kasar dari bahan tersebut melalui analisis laboratorium. Sangat penting mengetahui batasan kebutuhan protein kasar dan serat kasar yang baik untuk kebutuhan nutrisi jangkrik. Dari 5 bahan sayuran dan hijauan yang diketahui nilai PK tertinggi adalah sawi hijau dan nilai SK tertinggi adalah batang singkong muda. Namun pemberiannya harus disesuaikan dengan komposisi ransum yang sesuai dengan kebutuhan ternak jangkrik.

\section{DAFTAR PUSTAKA}

Novendra, A., I.W.Sukanata, dan I W. Budiartha. 2016. Analisis Pendapatan Peternakan Dari Usaha Budidaya Ternak Jangkrik. eJournal FADET UNUD. Universitas Udayana. Bali.

Muhammad, AS. 2015.Cerdas Budi Daya Jangkrik. Penerbit Pustaka Baru Press. Yogyakarta.

Rahmawati, Y. P. 2010. Produktivitas Usaha Budidaya Jangkrik kalung (Grilluss Bimaculatus). Skripsi Fakultas Peternakan. Institut Pertanian Bogor. Bogor.

Mansy. 2002. Performa Jangkrik Kalung (Gryllus Bimaculatus) yang diberi Kombinasi Kosentrat dengan Daun Sawi dan Daun Singkong Selama Masa Pertumbuhan.
Skiripsi, Program Sarjana. Institut Pertanian Bogor, Bogor.

Widiyaningrum P, 2003. Potensi jangkrik (Orthoptera: Gryllidae) sebagai sumber protein alternative satwa piaraan. Jurnal Ilmiah Sainteks. 10(2): 96-9.

Prayitno, 2006. Pemurnian Hormon Estrogen dan Testosteron dari Jangkrik Kalung. Laporan Penelitian. Fakultas Peternakan, UNSOED, Purwokerto.

Lakitan, B. 2010. Dasar-dasar Fisiologi Tumbuhan. Jakarta: PT Raja GrafindoPersada.

Dharmawati, S. , W. Neni, Supirah. 2019. Penggunaan Tepung Daun Eceng Gondok (Eichoria crassipes) pada Ransum Komersil terhadap Penampilan Jangkrik (Gryllidae).

Erniwati. 2012. Biologi Jangkrik (Orthoptera: Gryllidae) Budidaya dan Peranannya. FAUNA INDONESIA Vol 11 (2) Desember 2012:10-14.

Paimin. 1999. Mengatasi Permasalahan Beternak Jangkrik. Cetak 1. Penerbit Swadaya, Jakarta.

Hutabarat A. L. R., Y. C. Endrawati, A. M. Fuah. 2013. Subtitusi Dedak Halus Pada Pakan Jangkrik Kalung (Gryllus bimaculatus). Jurnal Ilmu Produksi dan Teknologi Hasil Peternakan, Vol. 01 No.3, HIm: 160-163. Institut Pertanian Bogor, Bogor. 
Jurnal IImiah Respati

Marhaendrik. 2021. Perbandingan Penggunaan Dua Jenis Hijauan Sebagai Pakan Terhadap Produksi Telur Jangkrik. Skripsi. Fakultas Pertanian. Universitas Respati Indonesia, Jakarta.

Panjaitan, I. 2012. Suplemntasi Tepung Jangkrik Sebagai Sumber Protein Pengaruhnya Terhadap Kinerja Burung Puyuh. Peternakan Politeknik Negeri Lampung. Lampung.
Rosyadi. 2001. Pengaruh Nisbah Kelamin dan Jenis Pakan Terhadap Reproduksi dan Konsumsi Jangkrik (Gryllus testaceus). Skripsi. Jurusan Ilmu Produksi Ternak. 